\title{
Comparison of the Efficacy of Daily and Weekly Oral Alendronate Treatment in Patients with Secondary Osteoporosis
}

\section{Sezer Acar $\odot$ Ahu Paketçi ${ }^{\oplus}$ Korcan Demir $\odot$ Ece Böber $\odot$ Ayhan Abacl (}

\author{
Sekonder Osteoporozlu Hastalarda Günlük ve \\ Haftalık Oral Alendronat Tedavisinin Etkinliğinin \\ Karşılaştırılması
}

\begin{abstract}
Objective: The use of alendronate, one of the bisphosphonates that can be used orally in the treatment of osteoporosis, has become widespread in recent years. In this study, we aimed to compare the efficacy of these two different treatment regimens such as weekly and daily oral alendronate in patients with secondary osteoporosis.

Method: Twenty-eight children and adolescent who were treated with oral daily or weekly alendronate with the diagnosis of secondary osteoporosis were included in this study. Clinical and laboratory features, bone mineral density (BMD) measurements of cases were retrieved from file records.

Results: This study included 28 children who were diagnosed with secondary osteoporosis due to various chronic diseases and who received weekly $(n=15)$ or daily $(n=13)$ alendronate. $B M D z$-score increased from $-3.41 \pm 0.50$ to $-0.50 \pm 0.67$ in the group receiving daily treatment $(p<0.001)$ and from $-3.03 \pm 0.86$ to $-0.22 \pm 0.62$ in the group receiving weekly treatment $(p<0.001)$. In both groups, the increase in BMD $z$-score and the percentage increase in density in $\mathrm{g} / \mathrm{cm}^{2}$ were similar ( $p=0.490$ and $p=0.271$ ).

Conclusion: This study demonstrated that both weekly and daily single dose of oral alendronate treatment provide similar and significant improvement in BMD. Daily or weekly alendronate treatment regimens can be used effectively and reliably in the treatment of secondary osteoporosis.
\end{abstract}

Keywords: Alendronate, bisphosphonate, bone mineral density, chronic diseases, secondary osteoporosis Öz

Amaç: Osteoporoz tedavisinde oral olarak kullanılabilen bisfosfonatlardan biri olan alendronatın kullanımı son yıllarda yaygınlaşmıştır. Bu çalışmada, sekonder osteoporozlu hastalarda, haftalık ve günlük oral alendronat tedavi rejimlerinin etkinliğini karşılaştırmayı amaçladık.

Yöntem: Sekonder osteoporoz tanısı ile günlük veya haftalık alendronat ile tedavi edilen 28 çocuk ve adolesan çalışmaya dahil edildi. Dosya kayıtlarından klinik ve laboratuvar özellikleri, kemik mineral yoğunluğu (KMY) ölçümleri kaydedildi.

Bulgular: Çalışmaya çeşitli kronik hastalıklara bağlı sekonder osteoporoz tanısı konulan ve haftalık (n=15) veya günlük ( $n=13)$ alendronat tedavisi alan 28 çocuk alındı. KMY z-skorları, günlük tedavi alan grupta $-3,41 \pm 0,50$ 'den $-0,50 \pm 0,67^{\prime} y e$ ( $p<0.001$ ); haftalık tedavi alan grupta ise $-3,03 \pm 0,86$ 'dan $-0,22 \pm 0,62^{\prime} y e$ yükseldi ( $p<0.001)$. Her iki grupta da KMY z-skoru artışı ve $\mathrm{g} / \mathrm{cm}^{2}$ cinsinden yoğunluk artış yüzdesi benzerdi $(p=0,490$ ve $p=0,271)$.

Sonuç: Bu çalışma, hem haftalık hem de günlük tek doz oral alendronat tedavilerinin KMY'de benzer ve istatistiksel olarak anlamlı iyileşme sağladığını göstermiştir. Günlük veya haftalık alendronat tedavi rejimleri, ikincil osteoporoz tedavisinde etkili ve güvenilir bir şekilde kullanılabilir.

Anahtar kelimeler: Alendronat, bisfosfonat, kemik mineral yoğunluğu, kronik hastalıklar, sekonder osteoporoz
Alındığı tarih: 19.11 .2018

Kabul tarihi: 08.02.2019 Online Yayın tarihi: 06.12.2019

Sezer Acar Dokuz Eylül Üniversitesi Tıp Fakültesi, Çocuk Endokrinoloji Bilim Dalı, İzmir - Türkiye dr.acarsezer@gmail.com ORCiD: 0000-0002-0768-835X

A. Paketçi 0000-0001-8048-8066 K. Demir 0000-0002-8334-2422

E. Böber 0000-0001-8828-0892

A. Abacı 0000-0002-1812-0321 Dokuz Eylül Üniversitesi Tıp Fakültesi, Çocuk Endokrinoloji Bilim Dalı, Izmir, Türkiye 


\section{INTRODUCTION}

Osteoporosis is characterized with a decrease in bone mineral density (BMD) and a deterioration in architecture of bone tissue with a consequent decrease in bone strength and susceptibility to bone fracture ${ }^{(1)}$. In childhood, there are various primary and secondary causes of osteoporosis ${ }^{(2)}$. Primary osteoporosis is a group of disorders that arises as a consequence of an intrinsic skeletal defect; on the other hand, secondary osteoporosis often occurs as a result of neuromuscular diseases, chronic inflammatory diseases, drugs (especially glucocorticoids), hematological malignancies, and endocrine diseases $(1,2)$. Secondary osteoporosis, previously known as an adult disease, has begun to be reported with an increasing rate in children in recent years, as a result of advances in the treatment of chronic diseases in children and consequent increase in life expectancy ${ }^{(1-4)}$.

Bisphosphonates, which are synthetic pyrophosphate analogs that inhibit bone resorption, have been used for a long time in the treatment of osteoporosis ${ }^{(1,2)}$. Different bisphosphonate agents that have been shown to be effective in the treatment of osteoporosis are available; however, there is no clear consensus on which of these agents have priority ${ }^{(2,3)}$. In addition, there are regional differences in dosage and duration of use of these agents. Intravenous pamidronate is widely used, and shown to be effective in the treatment of primary and secondary osteoporosis ${ }^{(2)}$. Alendronate, an agent in the bisphosphonate group, is preferred in recent years for its advantages such as its oral use, better compliance, lower cost, and effectiveness in the treatment of secondary osteoporosis ${ }^{(1,3-5)}$. Firstly, oral alendronate treatment was used in postmenopausal osteoporotic adult women and significant improvement in BMD was reported ${ }^{(6,7)}$. In the following years, Ünal et al. (4) firstly reported that oral alendronate was effective and safe in the treatment of secondary osteoporosis in children. Then, the single dose of daily or weekly oral alendronate was demonstrated to be effective in the treatment of secondary osteoporosis in children $(2-5,8-10)$. However, in the literature, there is no study comparing the efficacy of daily and weekly oral alendronate treatment regimens in childhood. Therefore, in this study, we aimed to retrospectively compare the efficiency of weekly and daily oral alendronate therapy in children with secondary osteoporosis.

\section{MATERIAL and METHODS}

A total of 28 children who were diagnosed with secondary osteoporosis due to various chronic diseases and treated with weekly $(n=15)$ or daily $(n=13)$ oral alendronate in our center between 2005 and 2016 were included in this study. The diagnostic approach of secondary osteoporosis in cases included in this study varied according to the date of diagnosis. In patients admitted before 2007, the diagnosis of osteoporosis was made by considering only BMD z-score, while in patients admitted after 2007 it was based on International Society for Clinical Densitometry (ISCD) criteria established in 2007 and $2014{ }^{(11,12)}$. Nutritional vitamin D and calcium deficiency, hypogonadism, gastrointestinal system disease (gastro-esophageal reflux, peptic ulcer, and achalasia) in which alendronate therapy is contraindicated, and patients receiving other types of bisphosphonate treatment were excluded from the study. Patients included in the daily alendronate treatment protocol, patients weighing $\leq 30 \mathrm{~kg}$, and $>30 \mathrm{~kg}$ had received daily doses of $5 \mathrm{mg}$, and $10 \mathrm{mg}$, respectively. In the weekly alendronate treatment protocol, patients weighing $\leq 30 \mathrm{~kg}$, and $>30 \mathrm{~kg}$ had received weekly doses of $35 \mathrm{mg}$, and $70 \mathrm{mg}$, respectively. The current study was approved by the local ethics committee in light of the WMA Declaration of Helsinki: Ethical Principles for Medical Research Involving Human Subjects (2017/08-04). Alendronate was given with the patient laid in supine position and the he/she was not allowed to be fed for $\mathbf{3 0}$ minutes.

Clinical, anthropometric, and laboratory characteristics of patients including age at diagnosis, gender, height, height standard deviation score (SDS), height-for-age, body mass index (BMI), the type of chronic disease, history of steroid usage, bone fracture, calcium and vitamin D intake; puberty status, duration of oral alendronate treatment, side effects 
of the treatment, serum levels of calcium, phosphorus, alkaline phosphatase (ALP), 25-hydroxy-vitamin $D$, and areal BMD results were recorded from the hospital files of each patient. BMD was measured from posteroanterior aspect of spinal vertebrae (L1-L4) using dual-energy X-ray absorptiometry (DEXA, Hologic QDR 4500W). BMD z-score was calculated by comparing these measurements with normal BMD values obtained from age-, and gendermatched healthy Turkish children in our region ${ }^{(13)}$. Height age was taken into account during calculation of BMD z-score.

Statistical analyses of the data were conducted with SPSS 24.0 (IBM Corp., Armonk, New York). The distribution of data was evaluated with the Kolmogorov-Smirnov test. For comparisons of numerical variables, the independent sample t-test or Mann-Whitney U-test was used according to fitness of measured parameters to normal distribution. In the comparison of two dependent groups, paired-t test or Kruskall Wallis test was performed according to fitness of measured parameters to normal distribution. Categorical data were expressed as frequency (\%), while numerical data were expressed as median (25-75 $5^{\text {th }}$ percentile) or mean \pm standard deviation. In all statistical tests, $p$ values $<0.05$ were considered as statistically significant.

\section{RESULTS}

The clinical and anthropometric characteristics of the 28 patients included in the study are summarized in Table 1. Among these cases, 13 (46.4\%) were male and 15 (53.6\%) were female. In the study group, the patients had neurological diseases $(n=15$ : $53.6 \%)$, connective tissue disorders ( $n=12: 42.8 \%$ ) and hematological malignancy (acute lymphoblastic leukemia) ( $n=1: 3.6 \%)$. The median age at the beginning of the treatment in daily and weekly treatment groups were 13.2 (12.7-15.8) and 12.7 (10.6-14.0) years, $(p=0.007)$ and the median duration of the treatment were 18 (13-27.5) and 14 (13-16) months, respectively $(p=0.235)$. Moreover, there was no statistically significant difference between the two groups in terms of gender, puberty status, BMI z-score, additional calcium intake, frequency of bone fractu$r e$, the dose and duration of steroid given ( $p>0.05$ ). Any side effects were not observed during the treatment in both groups. New fractures did not occur in patients during or after treatment.

Clinical and laboratory characteristics of the patients before and at the end of treatment are summarized in Table 2. At the beginning of the treatment, the height SDS, calcium, phosphorus, vitamin D, ALP, and BMD $z$-scores were comparable $(p>0.05)$. At the end

Table 1. The general characteristics of patients according to treatment groups.

\begin{tabular}{|c|c|c|c|}
\hline & $\begin{array}{l}\text { Daily treatment group } \\
\qquad(n=13)\end{array}$ & $\begin{array}{l}\text { Weekly treatment group } \\
\qquad(n=15)\end{array}$ & $\mathbf{p}^{\mathrm{a}}$ \\
\hline Age at the initiation of treatment (years) & $13.2(12.7-15.8)$ & $12.7(10.6-14.0)$ & $0.007^{b}$ \\
\hline Duration of treatment (months) & $18(13-27.5)$ & $14(13-16)$ & $0.235^{b}$ \\
\hline Male / Female & $5 / 8$ & $8 / 7$ & $0.431^{\mathrm{a}}$ \\
\hline Pubertal / prepubertal & $9 / 4$ & $8 / 7$ & $0.137^{\circ}$ \\
\hline Body mass index z-score & $-0.19(-0.53-0.35)$ & $-0.10(-0.60-1.16)$ & $0.311^{\mathrm{b}}$ \\
\hline Bone fracture $(+/-)$ & $3 / 10$ & $9 / 6$ & $0.052^{\circ}$ \\
\hline Steroid treatment $(+/-)$ & $9 / 4$ & $6 / 9$ & $0.122^{\mathrm{a}}$ \\
\hline The duration of steroid treatment (months) & $11.0(5.5-42)$ & $12(6-13.5)$ & $0.864^{b}$ \\
\hline Dose of steroid treatment & $15.0(11.5-30)$ & $12.5(10-15)$ & $0.328^{b}$ \\
\hline (mg/day prednisolone) & $4 / 9$ & $11 / 4$ & $0.024^{a}$ \\
\hline Additional vitamin D (400 U/day) (+/-) & $4 / 9$ & $9 / 6$ & $0.122^{2}$ \\
\hline \multicolumn{4}{|l|}{ Additional calcium (400 mg / day) (+/-) } \\
\hline \multicolumn{4}{|l|}{ Disease } \\
\hline - Neurological disease $(n=15)$ & 4 & 11 & $0.115^{\mathrm{a}}$ \\
\hline - Connective tissue disease $(n=12)$ & 8 & 4 & \\
\hline - Hematological malignancy $(n=1)$ & 1 & 0 & \\
\hline
\end{tabular}

${ }^{a}$ Ki-square test, ${ }^{b}$ Mann-Whitney $U$ test, + : present, -: absent, data were expressed as mean (25-75 percentile) and frequency 
Table 2. Comparisons of the clinical and laboratory characteristics at the beginning and end of treatment according to treatment groups.

\begin{tabular}{|c|c|c|c|c|}
\hline & & $\begin{array}{l}\text { Daily treatment group } \\
\qquad(n=13)\end{array}$ & $\begin{array}{l}\text { Weekly treatment group } \\
\qquad(\mathrm{n}=15)\end{array}$ & p-value \\
\hline \multirow[t]{3}{*}{ Height SDS } & Pre-treatment & $-1.17 \pm 1.47$ & $-1.58 \pm 1.61$ & $0.485^{\mathrm{a}}$ \\
\hline & Post-treatment & $-1.10 \pm 1.56$ & $-1.49 \pm 1.60$ & $0.524^{a}$ \\
\hline & ${ }^{c} p$-value & 0.776 & 0.262 & \\
\hline \multirow[t]{3}{*}{ Calcium (mg/dL) } & Pre-treatment & $9.9 \pm 0.4$ & $9.7 \pm 0.5$ & $0.184^{\mathrm{a}}$ \\
\hline & Post-treatment & $9.7 \pm 0.4$ & $9.5 \pm 0.3$ & $0.923^{a}$ \\
\hline & ${ }^{c} p$-value & 0.167 & 0.099 & \\
\hline \multirow[t]{3}{*}{ Phosphorus (mg/dL) } & Pre-treatment & $4.5 \pm 0.7$ & $4.4 \pm 0.5$ & $0.760^{\mathrm{a}}$ \\
\hline & Post-treatment & $4.3 \pm 0.4$ & $4.6 \pm 0.6$ & $0.116^{a}$ \\
\hline & ${ }^{c} p$-value & 0.139 & 0.246 & \\
\hline \multirow[t]{3}{*}{ ALP (IU/mL) } & Pre-treatment & 312 (190-339) & $209(175-310)$ & $0.108^{b}$ \\
\hline & Post-treatment & 261 (224-289) & $184(128-264)$ & $0.019^{b}$ \\
\hline & ${ }^{d} p$-value & 0.382 & 0.054 & \\
\hline \multirow[t]{3}{*}{ 25-hydroxy vitamin D } & Pre-treatment & $24.0(20.6-28.2)$ & $28.2(20.9-34.1)$ & $0.413^{b}$ \\
\hline & Post-treatment & $29.0(23.3-40.5)$ & $30.4(21.4-36)$ & $0.709^{b}$ \\
\hline & ${ }^{d} p$-value & 0.108 & 0.656 & \\
\hline \multirow[t]{3}{*}{ BMD z-score } & Pre-treatment & $-3.41 \pm 0.50$ & $-3.03 \pm 0.86$ & $0.269^{a}$ \\
\hline & Post-treatment & $-0.50 \pm 0.67$ & $-0.22 \pm 0.62$ & $0.233^{\mathrm{a}}$ \\
\hline & ${ }^{c} p$-value & $<0.001$ & $<0.001$ & \\
\hline Increase in BMD (SDS) & & $2.91 \pm 1.01$ & $2.79 \pm 1.04$ & $0.490^{\mathrm{a}}$ \\
\hline Increase in BMD (\%) & & $34.5 \pm 9.4$ & $30.6 \pm 9.2$ & $0.271^{\mathrm{a}}$ \\
\hline
\end{tabular}

${ }^{a}$ Independent sample T-test, ${ }^{b}$ Mann-Whitney $U$ test, ${ }^{c}$ Paired $T$ test, $d$ Wilcoxon test, The data are given in mean $\pm S D$ or median $(25-75$ percentile).

Table 3. Comparison of BMD increase according to steroid treatment status and additional calcium and vitamin D administration status of both groups.

\begin{tabular}{|c|c|c|c|c|}
\hline & & $\begin{array}{c}\text { Daily treatment } \\
\text { Increase in BMD (\%) }\end{array}$ & $\begin{array}{l}\text { Weekly treatment } \\
\text { Increase in BMD (\%) }\end{array}$ & ${ }^{\text {ap}}$-value \\
\hline \multirow[t]{3}{*}{ Steroid treatment } & + & $28.5(26.1-30.8)$ & $20.9(19.7-36.9)$ & 0.148 \\
\hline & - & $34.1(30.1-38.6)$ & $40.1(31.5-44.4)$ & 0.181 \\
\hline & ${ }^{a} p$-value & 0.148 & 0.272 & \\
\hline Additional calcium & + & $33.2(30.1-38.6)$ & $40.1(29.5-41.5)$ & 0.330 \\
\hline \multirow{2}{*}{ (600 mg/day elemental calcium) } & - & $21.0(19.6-35.8)$ & $30.8(26.2-43.7)$ & 0.224 \\
\hline & ${ }^{a} p$-value & 0.825 & 0.272 & \\
\hline \multirow[t]{3}{*}{ Additional Vitamin D (400 U/day) } & + & $26.5(21.0-33.5)$ & $30.8(26.2-43.7)$ & 0.280 \\
\hline & - & $33.2(29.7-40.0)$ & $40.1(29.5-41.5)$ & 0.414 \\
\hline & ${ }^{a} p$-value & 0.825 & 0.571 & \\
\hline
\end{tabular}

${ }^{a}$ Mann-Whitney $U$ test, +: present, -: absent, The data are given in median (25-75 percentile).

of the treatment, while serum ALP levels were significantly lower $(p=0.019)$ in the weekly treatment group, mean BMD z-scores were similar in the two groups $(p=0.233)$. In addition, the BMD z-score increased from $-3.41 \pm 0.50$ to $-0.50 \pm 0.67$ and from $-3.03 \pm 0.86$ to $-0.22 \pm 0.62(p<0.001)$ in the groups receiving daily, and weekly treatment, respectively (for both $p<0.001$ ) (Table 3). In both groups, the SDS increase in BMD and the percentage increase in density in $\mathrm{g} / \mathrm{cm}^{2}$ were comparable ( $p=0.490$ and $p=0.271$ ) (Figure).

\section{DISCUSSION}

It is well-known that peak bone mass is realized especially during childhood and adolescence, and therefore, factors affecting bone health during this time period play an important role in determining the lifetime risk of osteoporosis ${ }^{(3)}$. Unlike the mechanism of bone mineral loss in adults, osteoporosis in childhood is suggested to be due to inadequate development of bone tissue during this period ${ }^{(3,14)}$. 


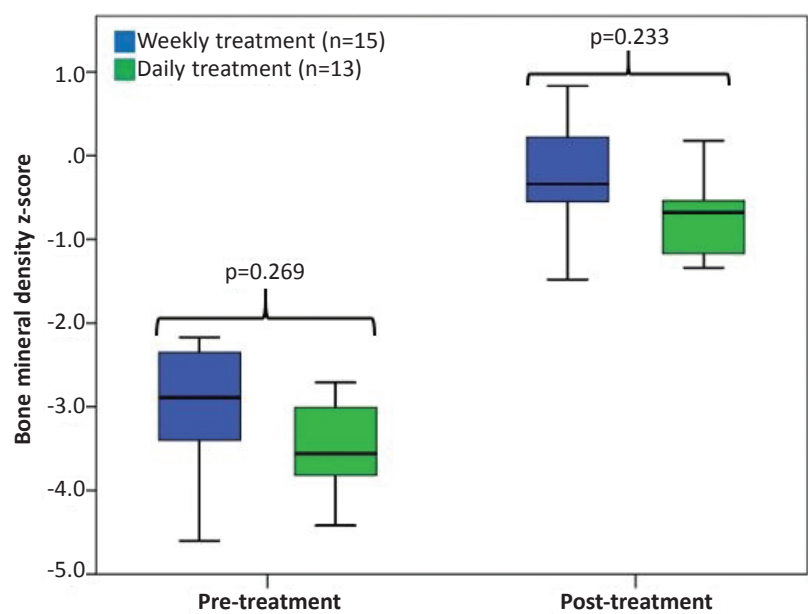

Figure. Comparisons of the treatment regimens before and after-treatment.

Thus, early diagnosis and treatment of secondary osteoporosis in childhood will help prevent future morbidities. In the current study, it was demonstrated that two groups with similar characteristics except for the age of onset of the treatment showed a significant and comparable increases in BMD in children with secondary osteoporosis. In the literature, there is no consensus on the dosage, and duration of weekly or daily oral alendronate treatment. In a study by Ünal et al. ${ }^{(4)}$, an annual average increase of $32.7 \%$ in BMD was demonstrated thanks to daily alendronate therapy in 22 pediatric patients with secondary osteoporosis, which was suggested this treatment regimen to be effective, reliable, and safe. Bianchi et al. ${ }^{(9)}$ reported that 38 children with collagen tissue disorders had significant increases in BMD compared to controls with daily alendronate therapy for 12 months, and 34\% of whom reached normal range of BMD. Sağlam et al. ${ }^{(8)}$ reported that in 22 pediatric patients with different chronic diseases and secondary osteoporosis, median BMD z-score increased from -4.03 to -2.43 with daily alendronate treatment in 24 months. In addition, some studies have shown that a single weekly dose of oral alendronate is effective and safe in the treatment of childhood osteoporosis ${ }^{(3,5,10)}$. A weekly regimen of oral alendronate in the treatment of secondary osteoporosis was demonstrated to be effective and reliable in 26 cases with cerebral palsy between 3-17 years of age Paksu et al. ${ }^{(3)}$, in 3 children with Duchenne / Becker muscular dystrophy Apkon et al. ${ }^{(5)}$, and in 10 children with leukemia or lymphoma Wiernikowski et al. ${ }^{(15)}$. In addition, Rugde et al. ${ }^{(10)}$ reported a significant increase in BMD with prophylactic oral alendronate treatment in 22 pediatric patients with normal BMD who had-been under steroid treatment due to chronic diseases. Taken together, these findings have suggested that both treatment regimens of alendronate are effective and reliable in the treatment of secondary osteoporosis. However, to the best of our knowledge, any study comparing weekly and daily alendronate treatment regimens is not available in the literature. Our study is the first to demonstrate that weekly and daily alendronate regimens showed comparable increases in BMDs of pediatric patients. In addition to the effect of weekly or daily oral alendronate treatment on BMD, adherence to treatment is an important problem among patients which has a significant impact on treatment response. A study conducted by Simon et al. ${ }^{(16)}$ with a large number of cases to determine patient preference for once weekly versus once-daily administration of oral alendronate demonstrated that onceweekly dose regimen may be more convenient and a better option for the maintenance of potential longterm compliance. Whereas the treatment compliance was not assessed in this study, the weekly alendronate regimen in the treatment of secondary osteoporosis may be preferred to the daily regimen because of longer dosing intervals.

Alendronate causes various side effects, mainly gastrointestinal system problems (gastroesophageal reflux, esophagitis, and peptic ulcus) ${ }^{(1,3,14)}$. In contrast, some studies have reported that oral alendronate is well tolerated and did not cause any side effects during treatment ${ }^{(3-5,9,10)}$. In a meta-analysis, Ghirardi et al. ${ }^{(17)}$ reported that weekly oral alendronate treatment did not increase the frequency of upper gastrointestinal side effects. Considering the file records of patients in our study, no side effects were recorded during daily or weekly oral alendronate treatment.

Bisphosphonate therapy may cause hypocalcemia as a result of reduced osteoclastic bone resorp- 
tion ${ }^{(18)}$. In contrast, Paksu et al. ${ }^{(3)}$ reported significantly higher serum calcium levels at the end of the treatment with oral alendronate compared to baseline in children with cerebral palsy. In the same study, the authors suggested that this elevation in serum calcium may be related to oral calcium and vitamin $D$ replacement therapy. In addition, it has been demonstrated that bisphosphonates affect serum phosphorus and ALP levels ${ }^{(3,19)}$. However, in this study, we have demonstrated that serum calcium, phosphorus, and ALP levels at end of the treatment did not change in both groups compared to the baseline levels.

Some studies demonstrated increased risk of bone fracture and diminished quality of life in patients with a BMD z-score lower than $-2.0^{(3,14)}$. It was reported that in adults, the risk of fracture increases 2 -fold in each SDS decrease in BMD (20). Clark et al. (21) showed a poor relationship between BMD and fracture risk in children, and suggested that further studies are needed to demonstrate this relationship in children. On the other hand, studies with limited number of cases with secondary osteoporosis have shown a significant reduction in the risk of bone fracture and an improvement in quality of life as a result of increase in BMD provided by oral alendronate $(4,22,23)$. In our study, 3 patients $(23.1 \%)$ in the daily group and 9 patients $(60 \%)$ in the weekly group had fractures before the treatment, and successfully, any significant bone fracture was not observed following alendronate treatment of these patients. These findings suggest that oral alendronate treatment reduces the risk of fracture in patients with secondary osteoporosis by providing a significant increase in BMD.

Factors that affect BMD positively include exercise, the amount of dietary intake of calcium and vitamin $D$, and daily exposure to sunlight ${ }^{(2,3)}$. Adequate vitamin $D$ intake is important for maintaining calcium and phosphorus absorption and regulating bone mineralization. In childhood, serum 25-hydroxyvitamin D level above $50 \mathrm{nmol} / \mathrm{L}(20 \mathrm{ng} /$ $\mathrm{mL}$ ) and daily vitamin $D$ intake of $600 \mathrm{U}$ are recommended ${ }^{(24,25)}$. However, the adequate serum level of 25 -hydroxyvitamin $\mathrm{D}$ is controversial and, in a meta- analysis, it has been reported that vitamin $D$ replacement therapy did not seem to be beneficial for bone health in children with normal vitamin D levels ${ }^{(26)}$. In line with these findings, bone mass and bone mineralization in children with osteogenesis imperfecta were not found to be associated with serum 25-hydroxy vitamin $D$ levels ${ }^{(27)}$. Whereas there is insufficient data on the effectiveness of calcium and vitamin $D$ intake in addition to bisphosphonate therapy, while adequate daily intake of calcium and vitamin $\mathrm{D}$ have been strongly recommended in patients under risk of osteoporosis ${ }^{(11,12)}$. In our study, serum calcium and 25-hydroxy vitamin D levels in both groups were normal before the treatment. Since this was a retrospective study, the daily amounts of calcium and vitamin D intake in the diet were not considered. On the other hand, in this study, some cases had taken vitamin $\mathrm{D}$ and calcium replacement in addition to oral alendronate treatment. The percentage of BMD increase in patients given calcium or vitamin $D$ replacement was higher without statistical significance. These findings suggested that additional calcium and vitamin $D$ replacement therapy have no contribution to BMD in patients with normal serum calcium and 25-hydroxy vitamin D levels.

This study has some limitations which should be acknowledged. The cases included in this study are heterogeneous for both groups and the number of subgroup cases are low. The response to alendronate treatment in secondary osteoporosis caused by various chronic diseases may vary, which was not considered in this study. In addition, measurements with DEXA give the spatial density of the bone and are affected by the size of the vertebra. Therefore, to avoid this undesirable effect, height-for-age and gender of the patients were taken into account for calculation of BMD z-score. However, measurement error of BMD due to incorrect patient position given by the technologist performed DEXA could not be excluded. According to the reports of the International Society for Clinical Densitometry (ISCD) in 2007 and 2013, it has been emphasized that osteoporosis should be identified and treated according to the condition of extremity and vertebral fractures, not just 
considering BMD z-score ${ }^{(11,12)}$. There are some cases treated only according to the BMD z-score regardless of bone fracture in our study, as in the case with some studies in the literature. Therefore, some patients treated with alendronate did not comply with the current definition of secondary osteoporosis.

In conclusion, although the diagnosis of some patients were conflicting, the current study has demonstrated that oral alendronate treatment is well tolerated and provides significant improvement in BMD in weekly or daily regimens. There was no significant difference as for the effect of weekly or daily oral alendronate treatments on BMD in patients who did and did not receive steroid, calcium and vitamin $D$ treatment. The single weekly oral alendronate regimen may be a more useful treatment option than daily regimen with the advantage of lower dose frequency. Consequently, weekly alendronate treatment regimen may be preferred to the daily regimen in the treatment of secondary osteoporosis.

Ethics Committee Approval: Dokuz Eylül University Non-Interventional Research Ethics Committee approval was obtained (2017/08-04).

Conflict of Interest: No conflict of interest has been declared by the authors.

Funding: The authors declared that this study received no financial support.

Informed Consent: Since this study was retrospective, informed consent was not obtained.

Etik Kurul Onayı: Dokuz Eylül Üniversitesi Girişimsel Olmayan Araştırmalar Etik Kurul onayı alınmıştır (2017/08-04).

Çıkar Çatışması: Yazarlar arasında çıkar çatışması bulunmamaktadır.

Finansal Destek: Çalışmanın finansal desteği bulunmamaktadır.

Hasta Onamı: Çalışmanın retrospektif olması nedeniyle hastalardan yazılı onam alınmamıştır.

\section{REFERENCES}

1. Ward L, Tricco AC, Phuong P, et al. Bisphosphonate therapy for children and adolescents with secondary osteoporosis. Cochrane Database Syst Rev. 2007;4:CD005324. https://doi.org/10.1002/14651858.CD005324.pub2

2. Ward LM, Konji VN, Ma J. The management of osteoporosis in children. Osteoporos Int. 2016;27:2147-79. https://doi.org/10.1007/s00198-016-3515-9

3. Paksu MS, Vurucu S, Karaoglu A, et al. Osteopenia in children with cerebral palsy can be treated with oral alendronate. Childs Nerv Syst. 2012;28:283-6. https://doi.org/10.1007/s00381-011-1576-9

4. Unal E, Abaci A, Bober E, Buyukgebiz A. Efficacy and safety of oral alendronate treatment in children and adolescents with osteoporosis. J Pediatr Endocrinol Metab. 2006;19:523-8.

5. Apkon S, Coll J. Use of weekly alendronate to treat osteoporosis in boys with muscular dystrophy. Am J Phys Med Rehabil. 2008;87:139-43. https://doi.org/10.1097/PHM.0b013e3181583ddc

6. Chesnut $\mathrm{CH}$, McClung MR, Ensrud $\mathrm{KE}$, et al. Alendronate treatment of the postmenopausal osteoporotic woman: effect of multiple dosages on bone mass and bone remodeling. Am J Med. 1995;99:144-52. https://doi.org/10.1016/S0002-9343(99)80134-X

7. Liberman UA, Weiss SR, Broll J, et al. Effect of oral alendronate on bone mineral density and the incidence of fractures in postmenopausal osteoporosis. The Alendronate Phase III Osteoporosis Treatment Study Group. N Engl J Med. 1995;333:1437-43. https://doi.org/10.1056/NEJM199511303332201

8. Sağlam H, Eren E, Papatya Çakır ED, Özboyacı E, Özgür T, Tarım Ö. The efficacy of alendronate in shildren with secondary osteoporosis. J Curr Pediatr. 2010;8:86-9.

Available from:http:// http://www.guncelpediatri.com/ makale_830/Sekonder-Osteoporozlu-CocuklardaAlendronat-Tedavisinin-Etkinligi-Ozgun-Arastirma.html

9. Bianchi ML, Cimaz R, Bardare M, et al. Efficacy and safety of alendronate for the treatment of osteoporosis in diffuse connective tissue diseases in children: a prospective multicenter study. Arthritis Rheum. 2000;43:1960-6. https://doi.org/10.1002/1529-0131(200009)43:9<1960:: AID-ANR6>3.0.CO;2-J

10. Rudge S, Hailwood S, Horne A, Lucas J, Wu F, Cundy T. Effects of once-weekly oral alendronate on bone in children on glucocorticoid treatment. Rheumatology (Oxford). 2005;44:813-8.

https://doi.org/10.1093/rheumatology/keh538

11. Baim S, Leonard MB, Bianchi ML, et al. Official Positions of the International Society for Clinical Densitometry and executive summary of the 2007 ISCD Pediatric Position Development Conference. J Clin Densitom. 2008;11:6-21. https://doi.org/10.1016/j.jocd.2007.12.002

12. Bishop N, Arundel P, Clark E, et al. Fracture prediction and the definition of osteoporosis in children and adolescents: the ISCD 2013 Pediatric Official Positions. J Clin Densitom. 2014;17:275-80.

https://doi.org/10.1016/j.jocd.2014.01.004

13. Goksen D, Darcan S, Coker M, Kose T. Bone mineral density of healthy Turkish children and adolescents. J Clin Densitom. 2006;9:84-90.

https://doi.org/10.1016/j.jocd.2005.08.001

14. Henderson RC, Lark RK, Gurka MJ, et al. Bone density and 
metabolism in children and adolescents with moderate to severe cerebral palsy. Pediatrics. 2002;110:e5.

https://doi.org/10.1542/peds.110.1.e5

Avalilable from: http://pediatrics.aappublications.org/ content/110/1/e5.long

15. Wiernikowski JT, Barr RD, Webber C, Guo CY, Wright M, Atkinson SA. Alendronate for steroid-induced osteopenia in children with acute lymphoblastic leukaemia or nonHodgkin's lymphoma: results of a pilot study. J Oncol Pharm Pract. 2005;11:51-6. https://doi.org/10.1191/1078155205jp145oa

16. Simon JA, Lewiecki EM, Smith ME, Petruschke RA, Wang L, Palmisano JJ. Patient preference for once-weekly alendronate $70 \mathrm{mg}$ versus once-daily alendronate $10 \mathrm{mg}$ : a multicenter, randomized, open-label, crossover study. Clin Ther. 2002;24:1871-86.

https://doi.org/10.1016/S0149-2918(02)80085-6

Available from: https://linkinghub.elsevier.com/retrieve/pii/ S0149-2918(02)80085-6

17. Ghirardi A, Scotti L, Vedova GD, et al. Oral bisphosphonates do not increase the risk of severe upper gastrointestinal complications: a nested case-control study. BMC Gastroenterol. 2014;14:5. https://doi.org/10.1186/1471-230X-14-5

18. Recker RR, Lewiecki EM, Miller PD, Reiffel J. Safety of bisphosphonates in the treatment of osteoporosis. Am J Med. 2009;122:22-32. https://doi.org/10.1016/j.amjmed.2008.12.004

19. Demir E, Bereket A, Ozkan B, Topçu M. Effect of alendronate treatment on the clinical picture and bone turnover markers in chronic idiopathic hyperphosphatasia. J Pediatr Endocrinol Metab. 2000;13:217-21. https://doi.org/10.1515/JPEM.2000.13.2.217

20. Genant HK, Cooper C, Poor G, et al. Interim report and recommendations of the World Health Organization Task-
Force for Osteoporosis. Osteoporos Int. 1999;10:259-64. https://doi.org/10.1007/s001980050224

21. Clark EM, Tobias JH, Ness AR. Association between bone density and fractures in children: a systematic review and meta-analysis. Pediatrics. 2006;117:291-7. https://doi.org/10.1542/peds.2005-1404

22. Houlihan CM, Stevenson RD. Bone density in cerebral palsy. Phys Med Rehabil Clin N Am. 2009;20:493-508. https://doi.org/10.1016/j.pmr.2009.04.004

23. Shiraki $M$, Nakamura $T$, Fukunaga $M$, Sone $T$, Usami $A$, Inoue T. A multicenter randomized double-masked comparative study of different preparations of alendronate in osteoporosis - monthly (four weeks) intravenous versus once weekly oral administrations. Curr Med Res Opin. 2012;28:1357-67. https://doi.org/10.1185/03007995.2012.709838

24. Misra M, Pacaud D, Petryk A, Collett-Solberg PF, Kappy M, Drug and Therapeutics Committee of the Lawson Wilkins Pediatric Endocrine Society. Vitamin D deficiency in children and its management: review of current knowledge and recommendations. Pediatrics. 2008;122:398-417. https://doi.org/10.1542/peds.2007-1894

25. Speiser PW, Clarson CL, Eugster EA, et al. Bisphosphonate treatment of pediatric bone disease. Pediatr Endocrinol Rev. 2005;3:87-96.

Available from: https://jhu.pure.elsevier.com/en/publications/bisphosphonate-treatment-of-pediatric-bone-disease- 6

26. Winzenberg T, Powell S, Shaw KA, Jones G. Effects of vitamin D supplementation on bone density in healthy children: systematic review and meta-analysis. BMJ. 2011;342:c7254. https://doi.org/10.1136/bmj.c7254

27. Edouard T, Glorieux FH, Rauch F. Predictors and correlates of vitamin $\mathrm{D}$ status in children and adolescents with osteogenesis imperfecta. J Clin Endocrinol Metab. 2011;96:3193-8. https://doi.org/10.1210/jc.2011-1480 